\title{
THICKNESS ANALYSIS OF BEECH STEMS USING ANNUAL RINGS
}

\author{
Michal Daniš , Jindřich Neruda $^{1}$ \\ ${ }^{1}$ Department of Engineering, Faculty of Forestry and Wood Technology, Mendel University in Brno, Zemědělská 1, \\ 61300 Brno, Czech Republic
}

Link to this article: https://doi.org/10.11118/actaun.2021.036

Received: 30. 3. 2021, Accepted: 14. 5. 2021

To cite this article: DANIŠ MICHAL, NERUDA JINDŘICH. 2021. Thickness Analysis of Beech Stems Using Annual Rings. Acta Universitatis Agriculturae et Silviculturae Mendelianae Brunensis, 69(3): 395-402.

\begin{abstract}
This article deals with the evaluation of a thickness analysis on the vuts of beech wood using annual rings. The study was performed at the state enterprise Lesy SR, a branch plant in Smolenice on the territory of Forrest District Majdán. In order to perform a thickness analysis of the beech logs, it was necessary to know the number of annual rings on the butt end and the number of annual rings on the small end. Based on these two quantities, it was necessary to derive the number of annual rings in the middle of the trunk. All these characteristics were related to the length of the stem and the thickness of the stem. The data set contained 1000 logs. For a period of 3 years - i.e. from 2017 to 2019 in total for all types of intentional felling, starting with tending intentional felling up to 50 years, tendingt intentional felling over 50 years and ending with prescribed final felling, incidential felling was not included in the investigation. The aim of this publication was to determine the thickness characteristics of beech stem logs, which are characterized in the territory of branch Smolenice by a full-wood stem and to create input quantities for a model log of a beech stem. The results include the average width of annual rings depending on the length of the stem, the average number of annual rings per 1 meter of length, the average reduction in the number of annual rings depending on the length recalculated per 1 meter of length, the average height increment. The results showed interesting findings, the largest average width of annual rings was recorded in improvement intentional felling over 50 years, despite advanced age. Another interesting finding was the average height gain of $0.5 \mathrm{~m}$. The average number of annual rings served to confirm the accuracy of the calculation of the stem thickness depending on the width of the annual ring. The average reduction in the number of annual rings showed the convergence of the stem in cm depending on the length of the cut.
\end{abstract}

Keywords: shape analysis, annual rings, beech, stem length, stem thickness, cuts

\section{INTRODUCTION}

\section{Construction of Annual Rings}

Main factors affecting the diameter increment distribution are species, age, crown form, sociological position of the tree in the stand, exposure, wind or snow stress and etc. Slope gradient plays a role as well (Neruda et al., 2013a).

Crossdating of annual ring series by means of their comparison is based on the following assumptions (Kotas, 2011; Neruda et al., 2013b; Neruda et al., 2013c):
- Each year, an annual ring develops.

- Annual ring series that were developing under identical or more frequently comparable, conditions exhibit the same kind of alternating narrow and wide annual rings.

Investigating the relation between annual ring width and factors affecting the growth of annual rings, we have to know the year of annual ring origin. It is easy to date annual rings from samples collected from live trees or felled trees in which the year of harvesting is known (Neruda et al., 2013a). Dating wood samples whose time of origin 
is unknown, we would need another already dated sample from the same period and optimally also from the same site. The oldest annual rings of hitherto living trees reach to more or less distant periods (Dittmar, 2003; Badal, 2012; Neruda et al., 2013b).

Structure and width of annual rings depend on tree species, site and its conditions, age of tree individual, social position of tree in the stand, silvicultural measures and location on the stem (Ellenberg, 1996).

Absolute values of annual rings decrease with the increasing age and the ratio of summer and spring wood changes, too (Hubač, 1982). The width of annual rings changes also in dependence on altitude and latitude and their combination. Decisive is always effect of some extreme climatic factor. Structure of annual rings and their width depend on tree species, site, age of individual, social position of tree in the stand, silvicultural measures and location on the stem. Absolute values of annual rings decrease with the increasing age and the ratio of summer and spring wood changes, too (Gullberg and Bjorheden, 2006). In the temperate zone, values of annual rings decrease with the increasing altitude due to mean air temperature decreasing with the increasing altitude. In contrast a limiting factor of growth in arid zones is the amount of precipitation; in this case, the increasing altitude ensures the increasing width of annual rings (Assmann, 1968; Heinimann, 1999; Neruda et al., 2013c).

The submitted publication deals with the investigation of the thickness analysis of the beech stem cuts in the region of western Slovakia, namely in districts Trnava and Pezinok. The survey was carried out only in forest stands with a 95\% or more representation of beech, i.e. monoculture. Thickness analysis was performed on harvested raw stems from all habitat species present as well as exposures to avoid distorting the data result.

\section{MATERIALS AND METHODS}

\section{Material}

Annual ring analysis was performed in 2017, 2018 and 2019 on manufactured raw stems from the stem base of which samples were taken, i.e. from the root (stump). It included regeneration intentional felling, i.e. overhead release felling as well as final felling, improvement intentional felling up to 50 years and improvement intentional felling over 50 years. The data were entered in the Microsoft Excel programme in which they were evaluated graphically for all felling systems together to obtain a statistical file large enough for the objective assessment.

The dataset consisted of 1000 surveyed logs of variable lengths - specifically 400 logs from regeneration intentional felling, 300 logs from improvement intentional felling up to 50 years and 300 logs from improvement intentional felling over 50 years. The data were evaluated for individual lengths ranging from $4 \mathrm{~m}$ to $12 \mathrm{~m}$. Trend line was used for better graphical depiction.

\section{Methodology}

Investigation of the number of annual rings on the butt end and small end was determined by a non-destructive method for logs, i.e. the disc was separated from the butt end of the beech stem and small end cut and the beech stem, their marking with a permanent colour with chalk, and the amounts of annual rings was subsequently counted and recorded in the relevant table. Length and midspan diameter were recorded for each cut. The methodology of saving annual rings is shown in Fig. 1.

Summarization of field data, i.e. records on annual rings of individual log butt and small ends and their redistribution according to assortment

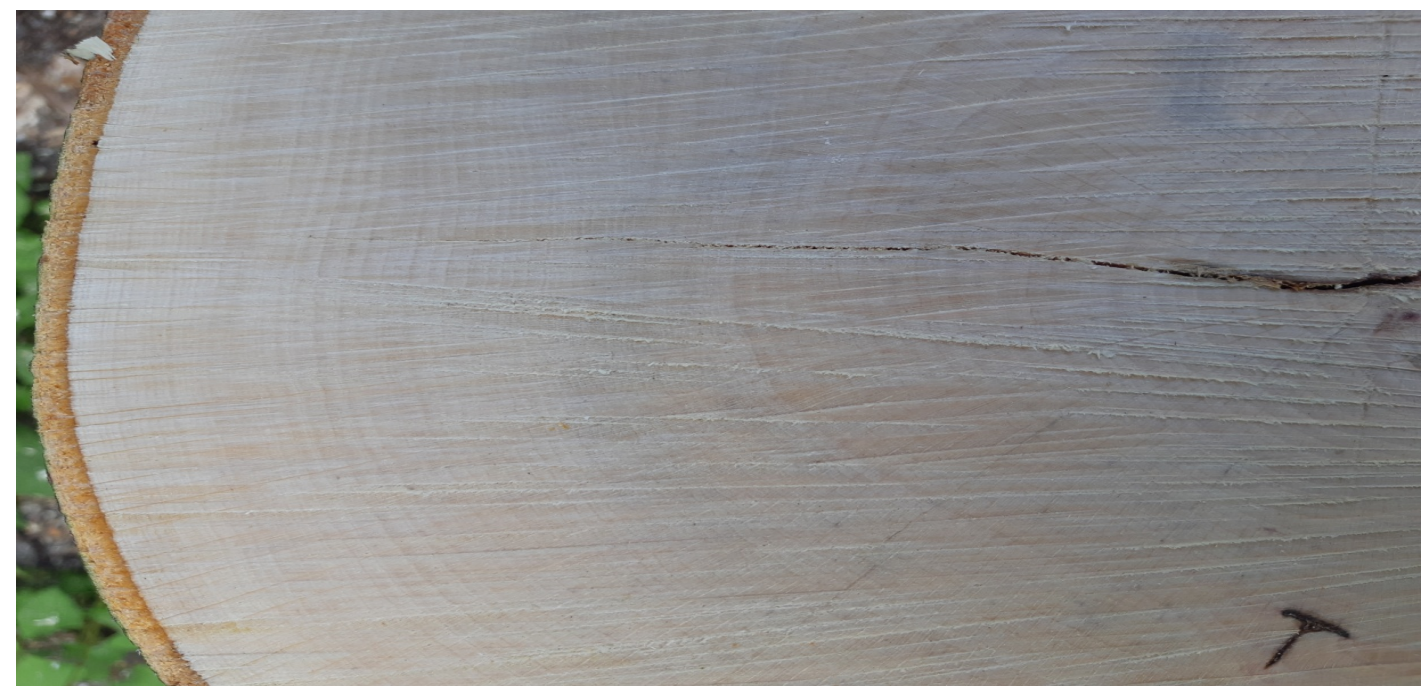

1: Annual rings of the butt end of beech stem Source: Michal Daniš, 2018 


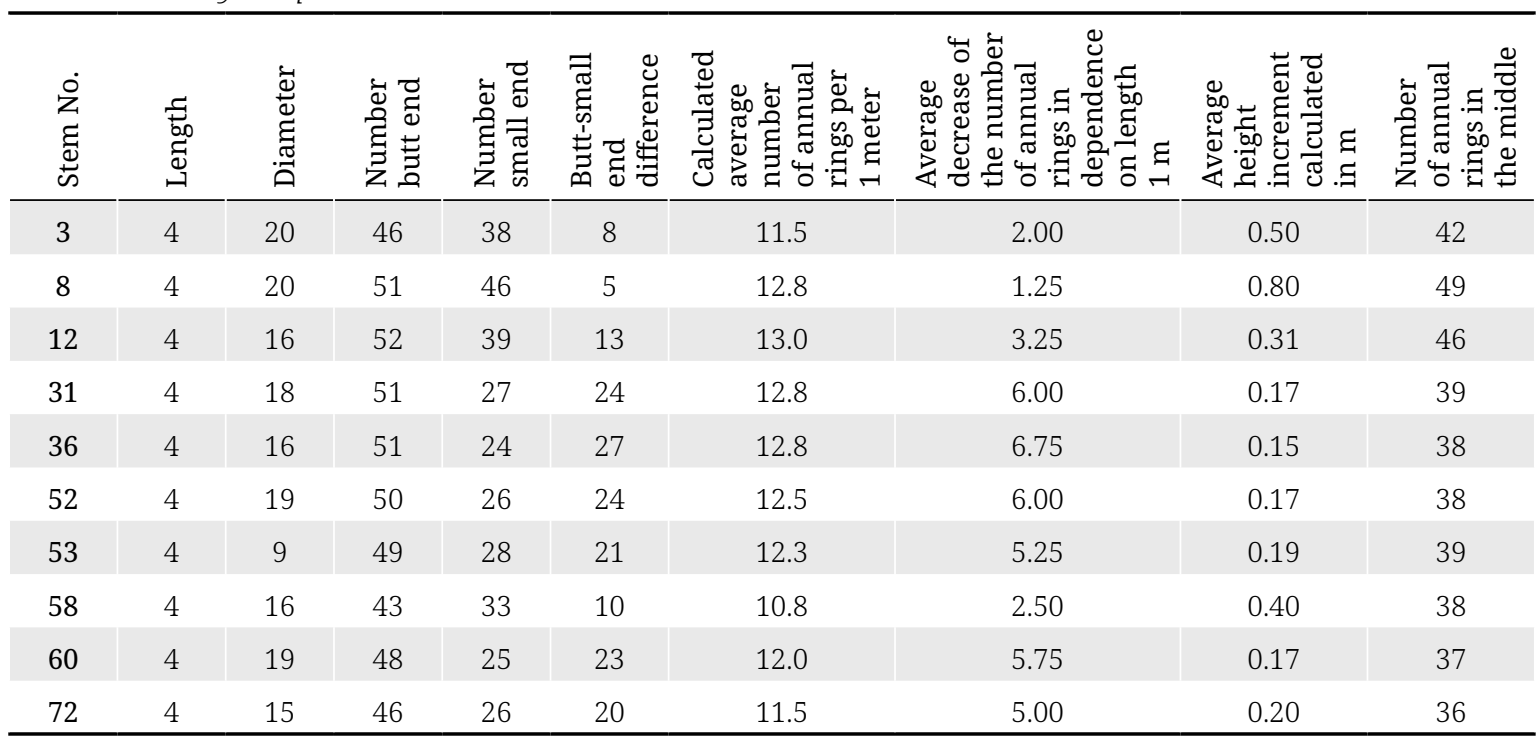

Source: Michal Daniš, 2019

lengths, gave groundwork for elaboration of growth curves. Annual rings in the middle of the stem were calculated according to the (1) because destructive method, i.e. division of assortments into meter sections was not chosen. The data summarized in this way were used to plot growth curves. The procedure of thickness analysis is shown in Tab. I. The formulas for the calculation are given below (1), (2), (3).

Formula for calculating number of annual rings in the middle of the log where:

$N \frac{l}{2}=n s e+\operatorname{adar} x\left(\frac{1}{2} l\right)$

nse........number of annual rings on the small end [pcs], l.............length $[\mathrm{m}]$,

adar.....average decrease in the number of annual rings [pcs] in dependence on length [1 $\mathrm{m}]$.

Formula for calculating average decrease in the number of annual rings in dependence on length, where:

$\operatorname{adar}=\frac{(n b e-n s e)}{l}$

l........length $[\mathrm{m}]$,

nbe....number of annual rings on the butt end [pcs].

Formula for calculating average height increment in $\mathrm{m}$ where:

ahic $=\frac{1}{\text { adar }}$

ahic .. average height increment calculated in $\mathrm{m}$ [1 m].

Average annual ring width - was calculated by adding a trend line on the annual ring width charts.

All data of thickness analysis of beech logs stem were statistically processed and subsequently graphically prepared in Microsoft Excel. There were calculated the average values, median and mode. These values were compared to each other and the most representative value was chosen. This was the value, which corresponed the most to the reality.

Trend lines were represented the most appeared value from the measured statistical values. These trend lines were inserted through MS Excel functioninsertion of trend lines (logarithmic shape of the line). Formula of the calculation is mentioned in Fig. 5.

\section{RESULTS}

\section{The Average Width of the Annual Rings of a Beech Stem}

The survey was divided according to the abovementioned felling systems for better interpretation of measured values.

\section{Tending Intentional Felling Up to 50 Years}

Fig. 2 shows that the variance of measured values increased with the increasing stem length being most visible with the stem length of $12 \mathrm{~m}$ and least visible with the stem length of $4 \mathrm{~m}$. In general, the width of annual ring was variable according to stem length but ranged most often within an interval from $2 \mathrm{~mm}$ to $2.5 \mathrm{~mm}$. Average width of annual ring for all stem lengths turns out to be $2.4 \mathrm{~mm}$.

\section{Tending Intentional Felling Over 50 Years}

Fig. 3 shows that the variance of measured values fluctuated with the increasing stem length. This is most visible with the stem length of $8 \mathrm{~m}$ and the least at the lengths of $4 \mathrm{~m}$ and $11 \mathrm{~m}$. It can be generally assumed that the width of annual ring was variable according to stem length, but most frequently ranged from $2 \mathrm{~mm}$ to $5 \mathrm{~mm}$. Average width of annual ring for all stem lengths turned out to be $3.1 \mathrm{~mm}$. 


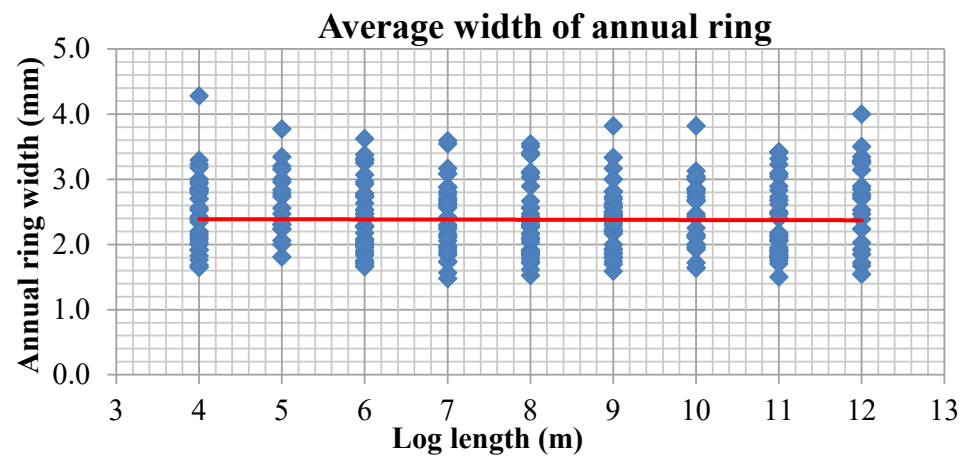

2: Tending intentional felling up to 50 years - annual rings average width

\section{Average width of annual ring}

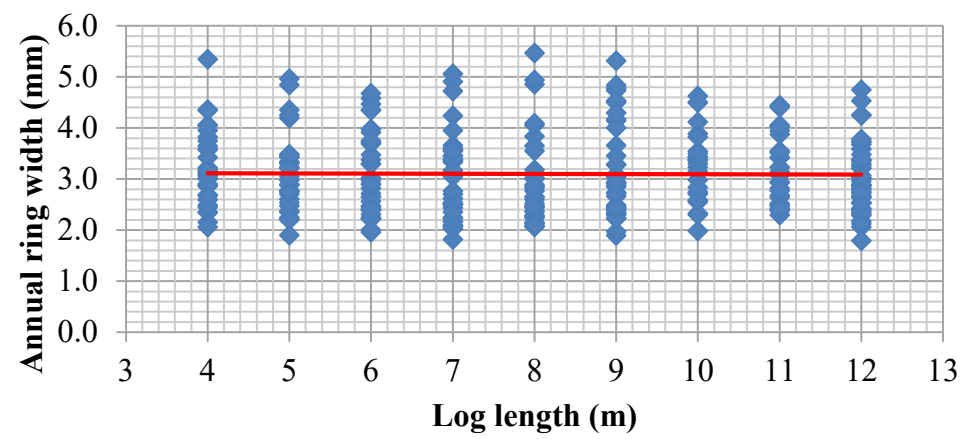

3: Tending intentional felling over 50 years - annual rings average width

\section{Average width of annual ring}

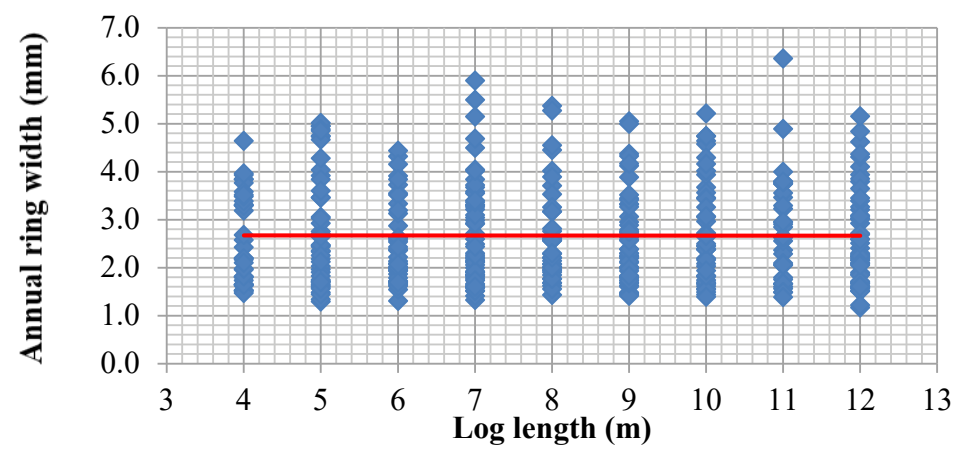

4: Prescribed final felling - annual rings average width

\section{Prescribed Final Felling}

Fig. 4 shows that the variance of measured values increases with the increasing stem length, which is most visible at the stem length of $7 \mathrm{~m}$. On the contrary, the smallest at the stem length of $4 \mathrm{~m}$ and most compact at the stem length of $12 \mathrm{~m}$. In general, we can assume that the annual ring width was variable according to the stem length. Most frequently ranging within an interval from $1.2 \mathrm{~mm}$ to $5.2 \mathrm{~mm}$. Some extreme values occurred as well. The extreme values were attributed to left solitary trees from young age up to the age of regeneration so-called wolf trees, characterized by high diameter increment in the stem part also at a higher age as compared with trees growing in canopy. Average width of annual ring for all stem lengths turns out to be $2.7 \mathrm{~m}$.

\section{Analysis of the Number of Annual Rings in a Beech Stem}

Fig. 5 the dependences of the number of annual rings on the central thickness in all types of prescribed felling. The graph shows that the entire spectrum of thickness was covered, from the youngest to the oldest individuals. Trend lines mark the average values of the number of annual rings on the butt end, in the middle of the log and on its small end, corresponding to a given central thickness of the beech stem log at a minimum 


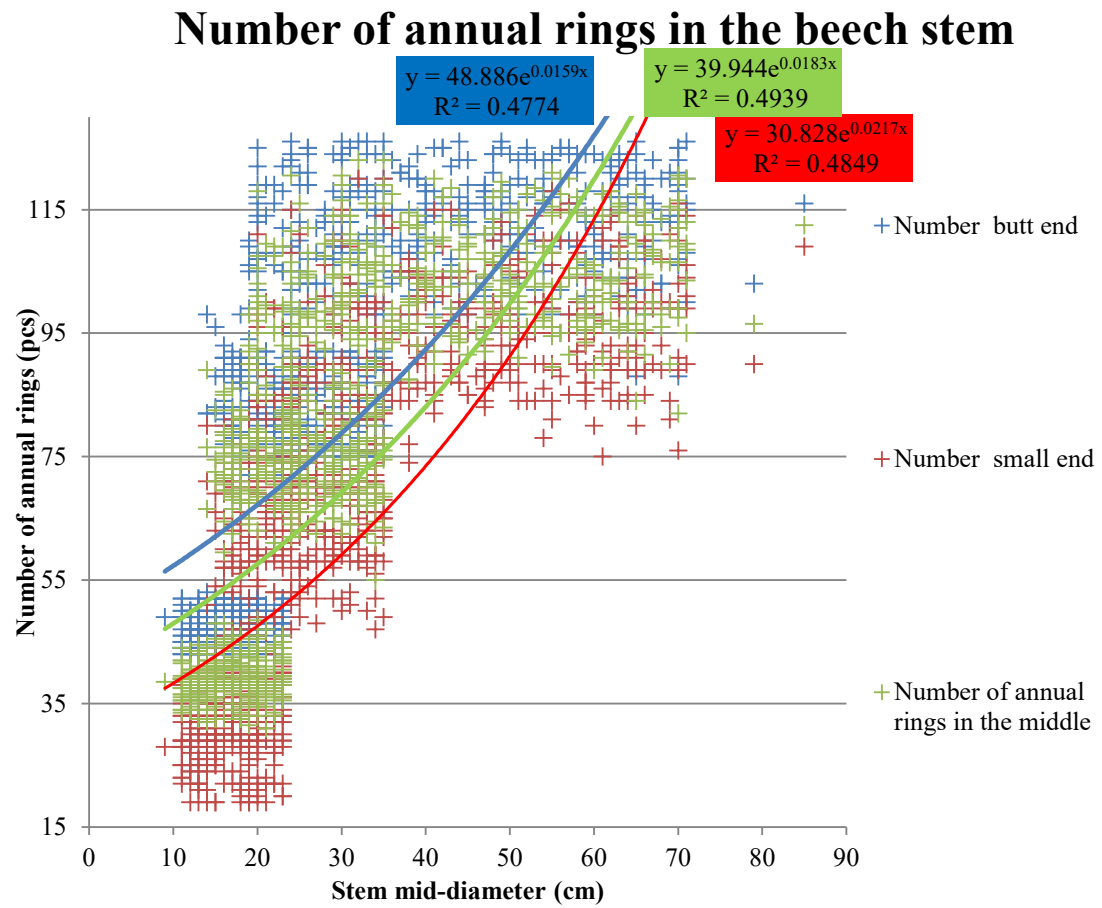

5: Beech stem annual rings number

stem length of $1 \mathrm{~m}$ or more, rounded to the whole meter. They also drawed the average beech stem with a starting cut length of $1 \mathrm{~m}$. After connecting with the average width of the annual rings in the previous part, we get a graphic representation of the shape of the log. The shape of the log would be multiplied by the average width of the annual ring and the number of annual rings on the butt end of the stem in the middle of the stem length, and, on the small end of the stem, the connection would create a model shape of the beech stem log.

\section{Shape Analysis of Beech Stem}

Fig. 6 shows that the average number of annual rings per $1 \mathrm{~m}$ decreases with the increasing stem length and in general. The value becomes equalized

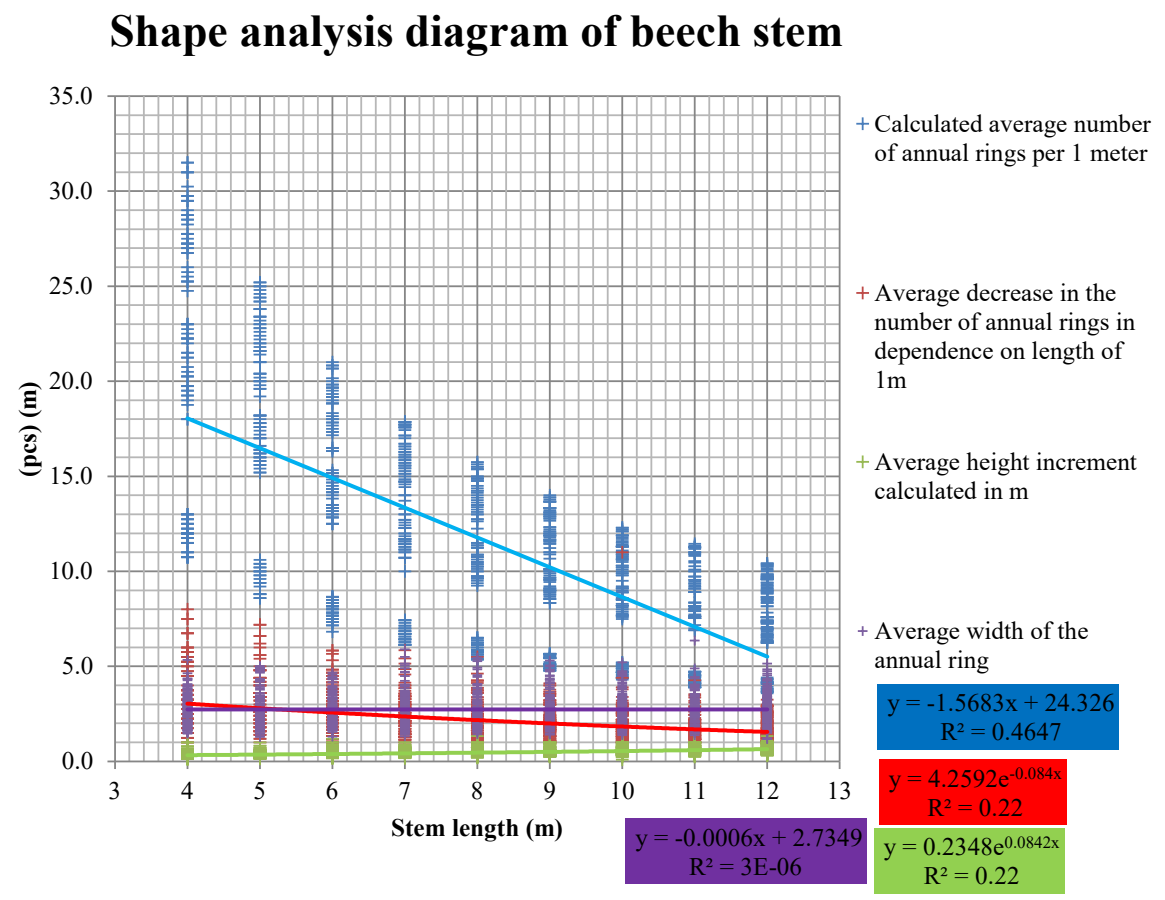

6: Beech stem annual rings diagram 
with the increasing stem length. This is most visible with the stem length of $4 \mathrm{~m}$, where the values range from 10 to 32 and with the stem length of $12 \mathrm{~m}$ only from the value of 3 to the value of 11 . Average decrease in the number of annual rings in dependence on stem length was of similar character. The highest and the lowest variance being recorded with the lengths of $4 \mathrm{~m}$ and $12 \mathrm{~m}$. respectively. In general, the values become equalized with the increasing stem length. The value of average height increment slightly increases with the increasing stem length ranging from $0.5 \mathrm{~m}$ to $0.9 \mathrm{~m}$ per year. This value depended mainly on the soil quality (the place where the tree grows). Average value coming into consideration would be $0.7 \mathrm{~m}$. The average width of the annual ring is $2.73 \mathrm{~mm}$ per year in all types of intentional felling.

\section{DISCUSSION}

Shape analysis of beech stem logs showed interesting results. With the investigation of dendrochronology of beech dealt (Neruda et al., 2013a), who stated that beech wood is classified as less suitable wood for densitometric studies, with difficulty in performing wood structure analysis. European beech (Fagus sylvatica L.) is the most represented deciduous forest in the forests of Central Europe (Dvořák, 2005), i.e. also in the area of Smolenice branch plant. In the case of improvement intentional felling up to 50 years, the differences were minimal and this phenomenon can be attributed to the young age of the stand and thus lower variability in the number of annual rings. There already was a greater difference in improvement intentional felling over the age of 50 than in the previous type of felling. Dittmar et al. (2003) found that the lower altitudes of Central Europe have lower temperatures and higher precipitation during the growing season, which encouraged the formation of wide annual rings on beech.

The number of annual rings and annual ring characteristics were calculated for the beech stem, but the average values cannot be generalized for the rest of Slovakia, they were strictly related only to the forest beech "Little-Carpathian" occurring in the Smolenice branch. The taper curve of the beech stem log, i.e. average, can be created by multiplying the number of annual rings on the butt end, the number of annual rings in the middle of the stem length and on the stem small end, by the average width of the annual rings to obtain the model stem thickness (Štefančík and Bošel'a, 2014). These model values would not always correspond to reality with $100 \%$ accuracy. The tree grows faster at a young age, and thus the width of the annual rings, the height increase and the average decrease in the number of annual rings is certainly higher than the average value, but at an older age, these values are often several times lower (Klvač et al., 2011). For most economically important trees, the width of the annual ring is 1-5 mm (Štefančík and Bošel'a, 2014). Trees with well-developed crowns show increments of 5-10 mm, poplar up to $15 \mathrm{~mm}$ (Štefančík and Bošel'a, 2014). The width of annual rings around the perimeter of the stem is very variable, which is related to the often eccentrically placed core (Ellenberg, 1996). Krammer (1982) monitored beech weight gain using dendrometers in the Lower Saxony region of Germany. They found that the formation of beech thickness gain at higher altitudes, according to their research, responded positively to the duration of sunlight.

The investigation of the thickness analysis of the beech stem always took place on the stem base, i.e. separated from the stem, where even after subtraction for the correctness of the investigation, the actual age determined by the conservation of annual rings and the age written in the forest management plan were compared. The quality of the wood cannot be inferred from the width of the annual rings, but the smoothness of the stem is decisive (Assmann, 1968).

An interesting finding was that the same trees, e.g. beech stems, were the same age but diametrically different in thickness after the analysis of annual rings (Štefančík, 1974). From this we can conclude that trees are like human beings with different variability in height, thickness, morphology and growth (Šmelko, 2007), despite the fact that they belong to one tree species - beech, while growing in the same habitat and in the same unit of spatial distribution of the forest.

\section{CONCLUSION}

In conclusion, we can state that there were differences in the thickness of annual rings in individual types of felling. An interesting finding was that the largest average width was reached within improvement intentional felling over 50 years. This phenomenon was probably caused by a positive selection in improvement intetional interventions (Štefančík, 2015) and the application of the preparatory felling, when a light increase occurs after the tending execution. This phenomenon wass also confirmed by the average height gain, which was calculated at the level of $0.7 \mathrm{~m}$, which was in fact a high value. Assman (1968) also achieved similar results, reporting an average height gain of $0.5 \mathrm{~m}$ for beech. This value was attributed in the youth to sub-level felling, when trees grow too fast under the light and are grown in a dense canopy (Schweingruber, 1996). 
This publication provides an insight into the shape characteristics of beech logs in the territory of the Smolenice branch. We can see from it the average widths of annual rings, the average number of annual rings on the small end, pin and in the butt midspan of the log. From this we can derive the tapper curve of beech stem log and its characteristics such as the convergence of the stem, expressed in thickness depending on the length with the help of an average reduction in the number of annual rings. Globally, we can create from the measured data the assumed average model stem, which was found in all types of felling, and based on this stem, we can consider the potential average monetization in the future.

\section{REFERENCES}

ASSMANN, E. 1968. Theory of forest yield [in Slovak: Náuka o výnose lesa]. Bratislava: Príroda.

BADAL, T. 2012. Regional use of forest biomass for heat production with a focus on forestry [in Czech: Regionální využívání lesní biomasy pro výrobu tepla se zaměřením na lesní hospodářství]. Biom.cz. [Online]. Available at: http://biom.cz/cz/odborne-clanky/regionalni-vyuzivani-lesni-biomasy-provyrobu-tepla-se-zamerenim-na-lesni-hospodarstvi [Accessed: 2020, June 22].

DITTMAR, C., ZECH, W. and ELLING, W. 2003. Growth variations of Common beech (Fagus sylvatica L.) under different climatic and enviromental conditions in Europe-a dendroecological study. Forest Ecology and Management, 173(1-3): 63-78.

DVOŘÁK, J. 2005. Analysis of forest stand damages caused by the usage of harvester technologies in mountain areas. Electronic Journal of Polish Agricultural Universities, 8(2): 07.

EISENLAUER, M., GRAF, H. and TEIPEL, U. 2018. Process Technology for Waste Wood Processing. Chenie Ingenieur Technik, 90(4): 521-532.

ELLENBERG, H. 1996. Vegetation Mitteleuropas mit den Alpen in ökologischer, dynamischer und historischer Sicht. Stuttgart: Ulmer.

HEINIMANN, R. 1999. Ground-based harvesting technologies for steep slopes. In: Proceedings of the International Mountain Logging and 10 th Pacific Northwest Skyline Symposium. Corvallis. OR: Department of Forest Engineering, Oregon State University, pp. 945-958.

HUBAČ, K. 1982. Dendrometry [in Slovak: Dendrometria]. University of Forestry and Wood Technology in Zvolen. Zvolen: Editing center UFWT Zvolen.

GULLBERG, T. and BJORHEDEN, R. 2006. Transport and handling of forest energy bundles-advantages and problems. Biomass \& Bioenergy, 30(4): 334-341.

KLVAČ, R., DELVIN, G. et al. 2011. Forest Biomass Processing Glossary. $1^{\text {st }}$ Edition. Praha: Lesnická práce.

KOTAS, M. 2011. Energy audit of wood chip production technology [in Czech: Energetický audit technologie výroby lesní štěpky]. Reports of forestry research, 56(4): 329-336.

KRAMMER, H. 1982. Short-term growth reactions in beech depending on the weather and various tree bangs [in German: Kurzfristige Zuwachsreaktionen bei Buche in Abhangigkeit von Witterung und verschiedenen Baummerknalen]. Allgemeine Forst und Jagdzeitung, 153(4): 57-67.

NERUDA, J., SIMANOV, V., KLVAČ, R., SKOUPÝ, A., KADLEC, J., ZEMÁNEK, T. and NEVRKLA, P. $2013 \mathrm{a}$. Technique and technology in forestry - Part one [in Czech: Technika a technologie v lesnictví-Díl prvni]. Brno: Mendel University in Brno.

NERUDA, J., SIMANOV, V., KLVAČ, R., SKOUPÝ, A., KADLEC, J., ZEMÁNEK, T. and NEVRKLA, P. $2013 \mathrm{~b}$. Technique and technology in forestry - Part two [in Czech: Technika a technologie v lesnictví - Díl druhý]. Brno: Mendel University in Brno.

NERUDA, J., ULRICH, R., KUPČÁK, V., SLODIČÁK, M. and ZEMÁNEK, T. 2013c. Harvester technologies of forestry [in Czech: Harvestorové technologie lesni těžby]. Brno: Mendel University in Brno.

SCHWEINGRUBER, F. H. 1996. Tree rings and environment dendroecology. Berne: Paul Haupt Publishers.

ŠMELKO, Š. 2007. Dendrometry [in Slovak: Dendrometria]. Zvolen: Technical university of Zvolen.

ŠTEFANČÍK, I. 1974. Beech harvesting [in Slovak: Prebierky bukových žrd'ovín]. Forestry studies No. 18. Bratislava: Príroda.

ŠTEFANČÍK, I. 2015. Growth structure and production of beech stands with different regime of intentional felling [in Slovak: Rast. štruktúra a produkcia bukových porastov s rozdielnym režimom výchovy]. Zvolen: NLC.

ŠTEFANČÍK, I. and BOŠELA, M. 2014. An influence of different thinning methods on qualitative wood production of European beech (Fagus sylvatica L.) on two eutrophic sites in the Western Carpathians. Journal of Forest Science, 60(10): 406-416. 
Contact information

Jindřich Neruda: neruda@mendelu.cz (corresponding author) (c) $(1)\left(\begin{array}{l}\text { This work is licensed under a Creative Commons Attribution-NonCommercial-NoDerivatives } 4.0 \\ \text { (CC BY-NC-ND 4.0) International License }\end{array}\right.$ 